\title{
Performance of Retscreen 4 Software on PV Solar System
}

\author{
V.Baby Shalini, Kandula Praveen
}

\begin{abstract}
Vitality is a significant perspective in the present world. Because of the expansion in the populace and the lessening in oil and other vitality assets the power age utilizing sustainable power source has gotten progressively famous. The current vitality emergency has moved human endeavors towards searching for and utilizing sustainable power sources. One of the notable of these, is the sun powered vitality. The two notable reaping frameworks are PV and sun powered thermals. This undertaking attempts to mirror the Photovoltaic frameworks when all is said in done in first moment. Moreover, it considers the Efficiency investigation of the PVs by means of RETScreen 4 programming. The examination depends on the RETScreen library and NASA related area insights Energy effectiveness and sustainable power source advances can lessen vitality utilization and thusly vitality cost, just as GHG. In the last areas, budgetary investigation was completed to decide the monetary feasibility of such ventures and the likelihood for self-financing. Emanation investigations were likewise done dependent on the capacity for such activities to balance ozone depleting substance discharges and guarantee maintainability in the vitality part. This displays the achievability investigation of executing the photovoltaic framework. RET screen programming has been utilized for the financial examination. The product has additionally been utilized to get the climatic conditions like mugginess, temperature with the radiations. The impact of these conditions with the proficiency of the sun powered boards was likewise dissected.
\end{abstract}

Keywords - PV system, RET screen, Feasibility, Energy Analysis, Cost Analysis, Financial Analysis

\section{INTRODUCTION}

Sustainable power source is vitality that is gathered from inexhaustible assets, which are normally recharged on a human timescale, for example, daylight, wind, downpour, tides, waves, and geothermal warmth. In light of REN21's 2016 report, renewables contributed $19.2 \%$ to people's worldwide vitality utilization and $23.7 \%$ to their age of power in 2014 and 2015, separately. This vitality utilization is isolated as $8.9 \%$ originating from conventional biomass, $4.2 \%$ as warmth vitality (present day biomass, geothermal and sunlight based warmth), 3.9\% hydroelectricity and $2.2 \%$ is power from wind, sun based, geothermal, and biomass. Starting at 2015 around the world, the greater part of all new

Revised Manuscript Received on February 05, 2020.

* Correspondence Author

Mrs. V.Baby Shalini*, Assistant professor, Department of EEE, Jawaharlal Nehru Technological University Hyderabad College of Engineering Jagtial, (T.S), INDIA.

Mr. Kandula Praveen, PG Scholar, Dept of EEE, Jawaharlal Nehru Technological University Hyderabad College Of Engineering Jagtial (T.S), INDIA.

(C) The Authors. Published by Blue Eyes Intelligence Engineering and Sciences Publication (BEIESP). This is an open access article under the CC BY-NC-ND license (http://creativecommons.org/licenses/by-nc-nd/4.0/) power capacity introduced was inexhaustible. Sustainable power source assets exist over wide geological territories, as opposed to other vitality sources, which are amassed in a set number of nations. Fast sending of sustainable power source and vitality productivity is bringing about noteworthy vitality security, environmental change alleviation, and monetary advantages.

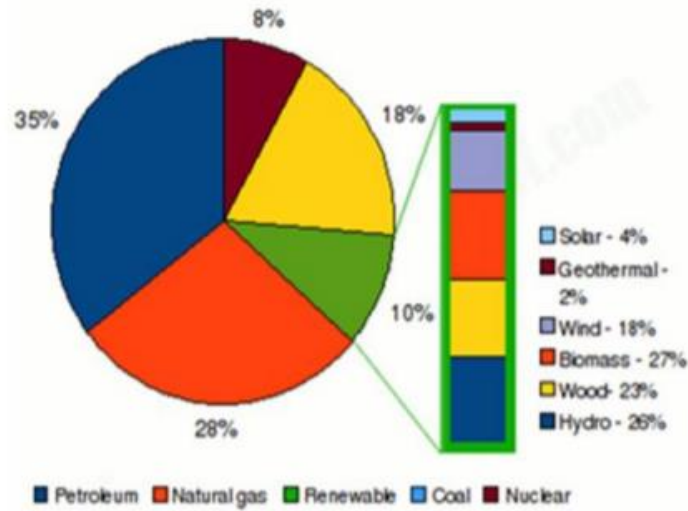

Figure 1:.renewable energy source

\section{SOLAR ENERGY:}

Maybe the most well known type of sustainable power source is sun oriented vitality. There are two primary innovations that fall under this classification: photovoltaic (PV) and concentrating sun oriented warm (CST). PV takes daylight and changes over it in to power by method for photovoltaic cells, which are made of semiconductor materials (frequently this material is silicon.) When daylight hits these cells, a part of that vitality is retained inside the material. This thumps the electrons free and permits them to stream openly. By placing metal contacts on the top or base of the cell, the current at that point is drawn off the cell for outside use. A gathering of these photovoltaic cells are packaged together into a casing, which is alluded to as a sunlight based board. Current, alongside cell voltage, characterize the power that the board is equipped for delivering. Bundle these boards together, and you have yourself a high-power sun based vitality framework. 


\section{Performance of Retscreen 4 Software on PV Solar System}

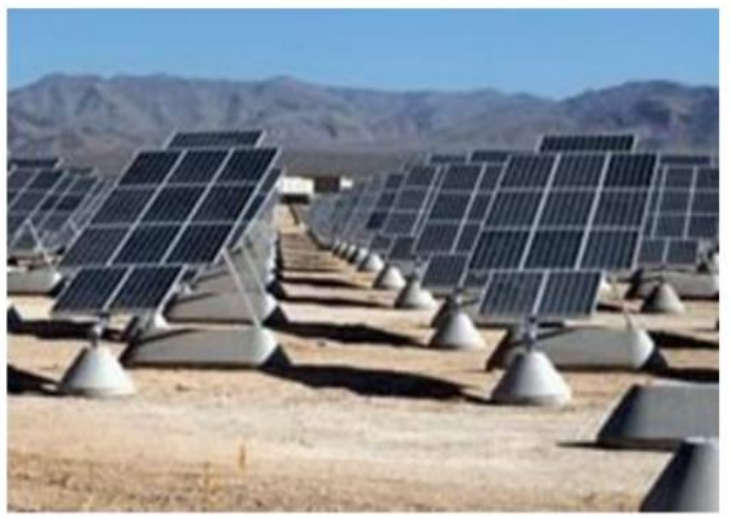

Figure 2: solar power plant

\section{RETSCREEN OVERVIEW}

The utilization of clean vitality innovations - that is, vitality proficient and Renewable vitality advancements (RETs) - has expanded incredibly in the course of recent decades. Advances once thought to be interesting or intriguing are presently business real factors, giving financially savvy options in contrast to traditional, petroleum derivative based frameworks and their related issues of ozone depleting substance emanations, high working expenses, and nearby contamination. So as to profit by these innovations, potential clients, choice and arrangement creators, organizers, venture agents, and gear sellers must have the option to rapidly and effectively survey whether a proposed clean vitality innovation venture bodes well. This examination takes into consideration the base venture of time , exertion \& uncovers whether a potential clean vitality venture is adequately encouraging to justify further examination.

This RETScreen Software is the main apparatus explicitly planned for facilitating pre-plausibility and attainability examination of clean vitality advancements. The center of the instrument comprises of an institutionalized and incorporated venture investigation programming it would be utilized worldwide to assess the vitality creation, life cycle expenses and ozone depleting substance outflow decreases for different kinds of proposed vitality proficient and sustainable power source advancements. All perfect vitality innovation models in RETScreen Software have typical look \& observe a particular approach to facilitate basic leadership - with solid resultsII.

Each model additionally incorporates coordinated item, cost \& climate databases, a point by point online client manual, all of this assist to drastically lessen the time \& cost related with getting ready pre-attainability considers. RETScreen4 Software is created in Microsft Excel. Thissoftware is speediest and simplest instrument for the estimation of reasonability of a potential clean vitality venture. Since RETScreen International contains such a lot of data thus numerous helpful highlights, its utility stretches out past pre-possibility and plausibility evaluation.

\section{CELL COLOUR CODING}

The client enters information into "concealed" worksheet cells. Every other cell that don't require input information are shielded to keep the client from erroneously erasing a recipe or reference cell. The RETScreen Cell Color Coding diagram exhibits the shading coding for information and yield cells.

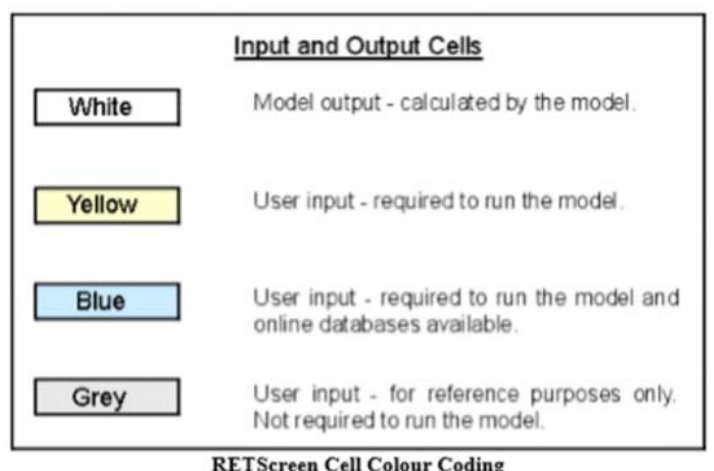

Figure 3.cellcolour coding

\section{METHODOLOGY}

\section{PHOTOVOLTAIC}

Photovoltaics (PV) is a term which covers the transformation of light into power utilizing semiconducting materials that display the photovoltaic impact, a wonder examined in physical science, photochemistry, and electrochemistry. A run of the mill photovoltaic framework utilizes sunlight based boards, each containing a few sun based cells, which produce electrical power. PV establishments might be ground-mounted, housetop mounted or divider mounted. The mount might be fixed, or utilize a sun powered tracker to follow the sun across the sky. Sunlight based PV has explicit focal points as a vitality source: its activity creates no contamination and no ozone harming substance discharges once introduced, it shows basic adaptability in regard of power needs and silicon has enormous accessibility in the Earth's outside layer. PV frameworks have the significant weakness that the power yield is reliant on direct daylight, so around $10-25 \%$ is lost if a tracking framework isn't utilized, since the cell won't be legitimately facing the sun consistently. Residue, mists, and different things in the climate likewise reduce the power yield. A total framework incorporates various segments that ought to be chosen mulling over your individual needs, site area, atmosphere and desires.

\section{SYSTEM COMPONENTS}

It might incorporate significant segments like; DC-AC power inverter, battery backup, framework and battery controller, helper vitality sources \& now and again the predetermined electrical burdens(machines) 


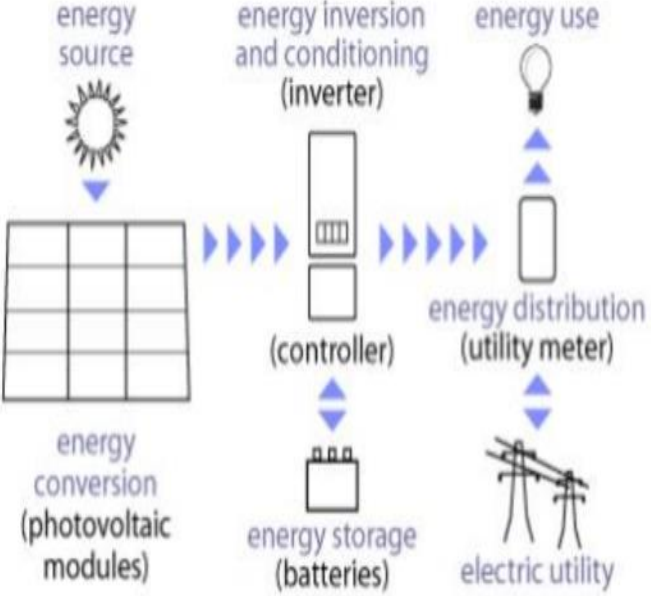

Figure.4 System components

Mainly PV Modules it converts sunlight photon energy to Dc electric power, Inverter it converts DC to AC electric power ,Battery for backup, Utility Meter, Charge controller.

Utility Meter - utility power is naturally given around evening time and during the day when the interest surpasses your sun oriented electric power generation. The utility meter actually turns backwards when sun oriented power generation surpasses house request, permitting you to credit any abundance power against future service bills.

Charge Controller - forestalls battery cheating , delays the battery life of your PV framework. What's more, a variety of parity of framework equipment; wiring, overcurrent, flood security and separate gadgets, and other power handling gear.

\section{FIVE STEP STANDARD PROJECT}

While an alternate RETScreen Clean Energy Technology Model is utilized for each of the innovations secured by RETScreen, a similar five stage standard investigation strategy is regular to every one of them. Therefore, the client who has figured out how to utilize RETScreen with one innovation ought to have no issue utilizing it for another. Since the RETScreen Software is created in Microsoft ${ }^{\circledR}$ Excel, each of the five stages in the institutionalized investigation method is related with at least one Excel worksheet.

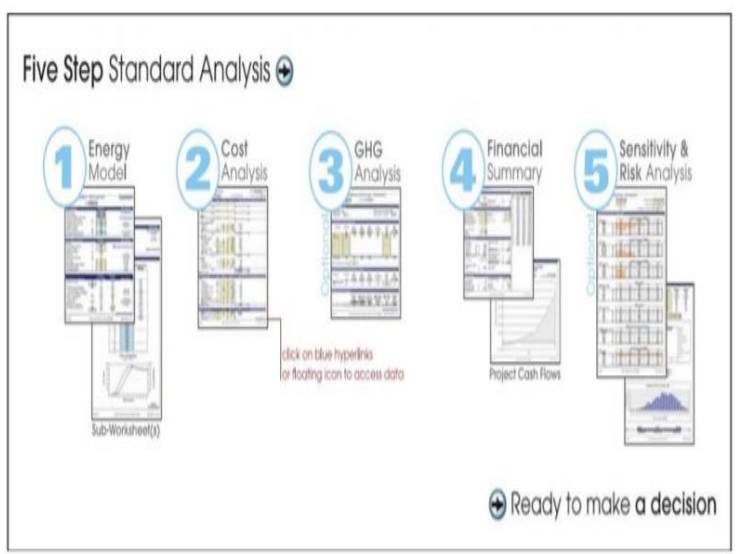

Figure 5. Five step analysis

\section{ENERGY MODEL:}

Right now, client determines parameters portraying the area of the energy venture, the kind of framework utilized in the base case, the innovation for the proposed case, the heaps (where pertinent), and the sustainable power source asset (for RETs). Thus, the RETScreen Software computes the yearly energy creation or energy investment funds. Regularly an asset worksheet, (for example, the "Sunlight based Resource" or the "Hydrology and Load" worksheet) or a "Hardware Data " worksheet or both accompanies the Energy Model worksheet as sub-worksheet(s). The calculations utilized in each innovation's Energy Model worksheet alongside their approvals can be found in the individual parts of this course reading

\section{COST ANALYSIS:}

Right now, client enters the underlying, yearly, and occasional expenses for given case framework just as credits for any base case costs that are dodged in given case (on other hand, client can enter gradual expenses straightforwardly). Client has the decision between playing out a pre-possibility or practicality study. For "Pre-practicality investigation," less itemized \& less accurate data is normally required while for an "Achievability examination," increasingly point by point and progressively accurate data is generally needed. Since computations carried out by this Software for progression are clear and generally straightforward (expansion \& duplication), the data appears in the online manual for each information and yield cell ought to be adequate for a total comprehension of this worksheet.

GHG EMISSION, REDUCTION ANALYSIS MODEL is worksheet of this software, enables the client to appraise the ozone harming substance outflow decrease (relief) capability of a given clean energy venture.. It figures the GHG outflow profile for a Base Case System (Baseline), and for the given Case System (clean energy venture). The GHG emanation decrease potential is gotten by consolidating the distinction of the GHG discharge factors with other data determined by RETScreen, for example, the yearly energy conveyed.

\section{RESULTS}

Project type: User selects the proposed project type considered from the ten options in the drop-down list: "Power," Note "power" means "electricity generation" in the RETScreen Model.

Technology: User selects the technology from drop-down list. 


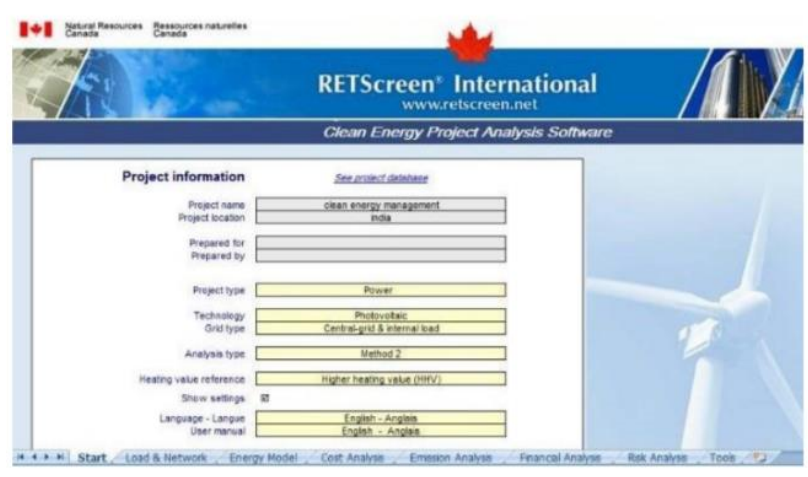

Figure 6.Retscreen start worksheet

Grid type: The user selects the grid type considered from the drop-down list. For central-grid and isolated-grid systems, the user also selects whether or not there is an internal load.

Analysis type: The user selects the type of analysis from the drop-down list.

If "Method 1" is selected,it need less information.

If "Method 2" is selected, it need more detailed information.

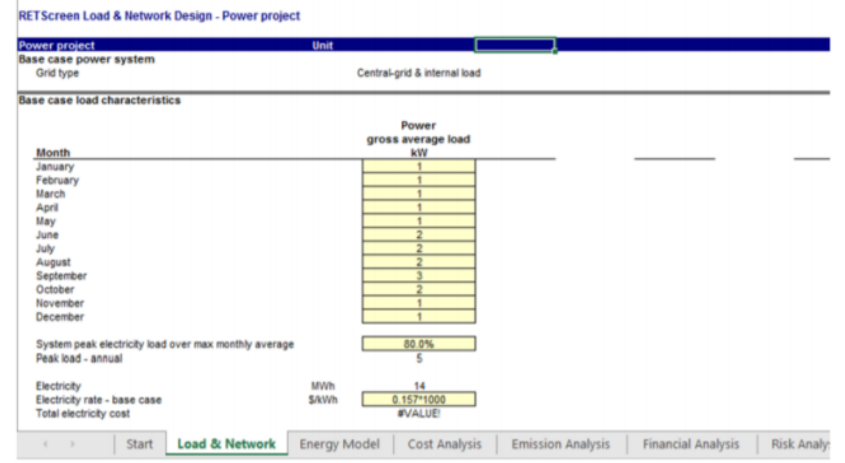

Figure 7. Retscreen Load \& Network Design

Base case power system: In this user provides information about the base case power system. The user enters the power gross average load on a monthly basis and, in the case of central-grid and isolated-grid systems, the electricity rate for the base case power system, in the"Base case load characteristics" section

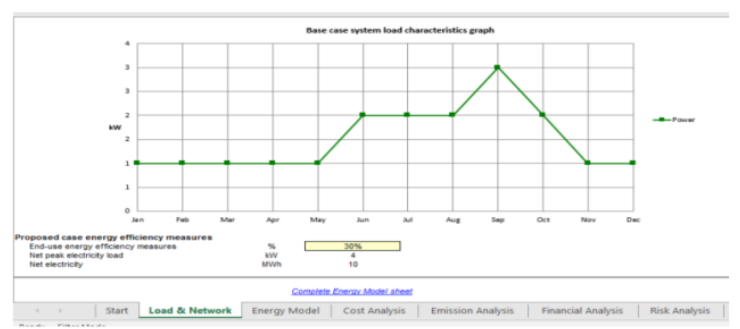

Figure.8 .Base load characteristics graph

Proposed case energy efficiency measure:

End-use energy efficiency measures: The user enters the percent of the base case power system's annual peak load (i.e. power net average load) that is reduced as a result of implementing the proposed case end-use energy efficiency measures. This value is used to calculate the power net average load in the "Proposed case load characteristics" section, the net peak electricity load and the net electricity use for the proposed case system. Typical values range from 0 to $25 \%$ depending on the measures implemented.

Net peak electricity load: The model calculates the annual net peak electricity load, which is the amount of power load required to meet the largest electricity load (excluding electricity used for heating and/or cooling) after the proposed case end-use implementation of energy efficiency measures.

Net electricity: The model calculates the annual net electricity use, which is the amount of energy required to run all the electricity loads (excluding electricity used for heating and/or cooling) after the implementation of the proposed case end-use energy efficiency measures.

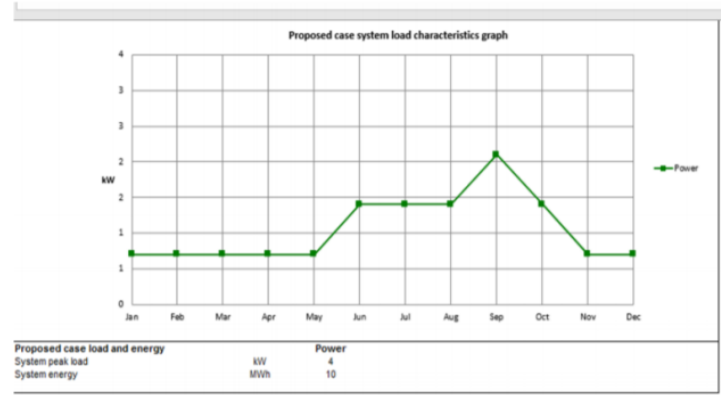

Figure.9. Proposed load characteristics graph

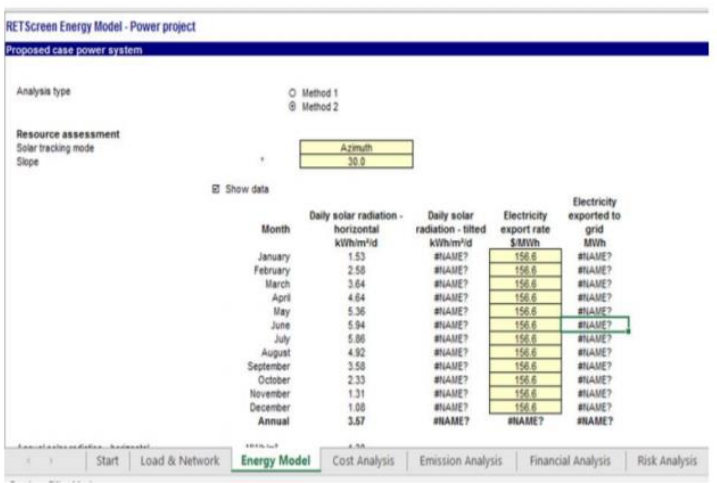

Figure.10. Energy model

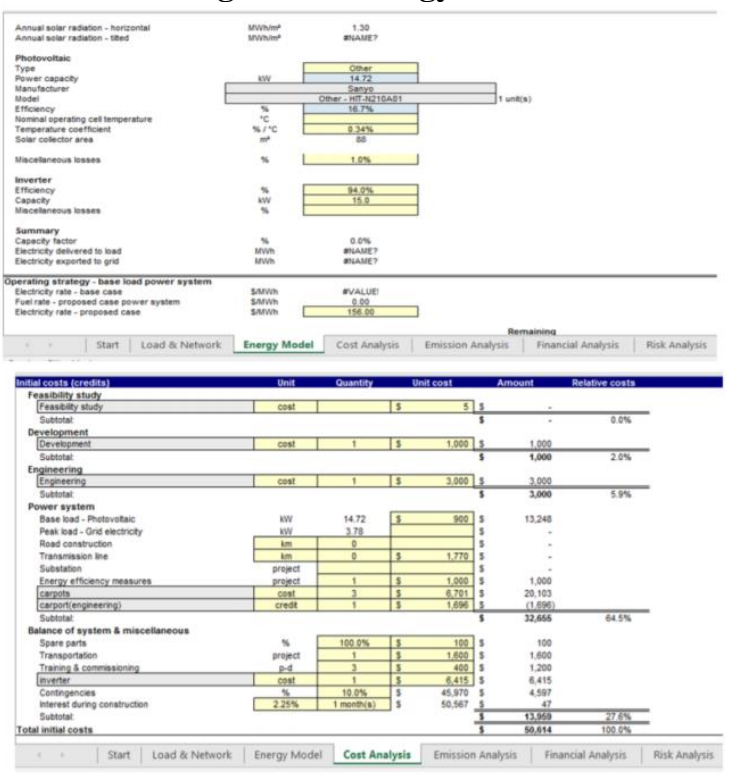

Figure.11. Cost analysis

Published By:

Blue Eyes Intelligence Engineering

\& Sciences Publication 


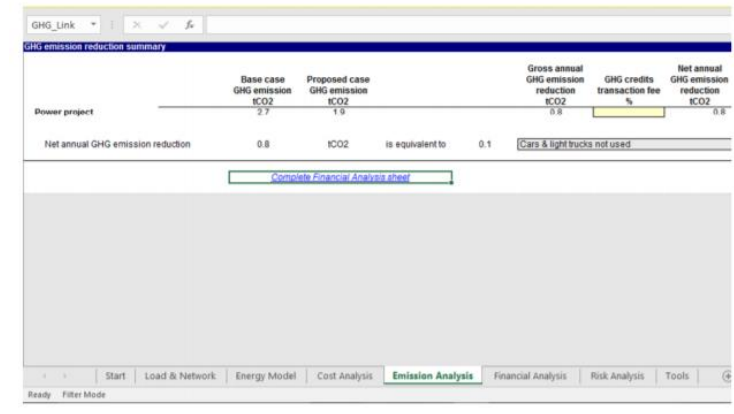

Figure.12.Emission analysis

\section{CLIMATE DATA}

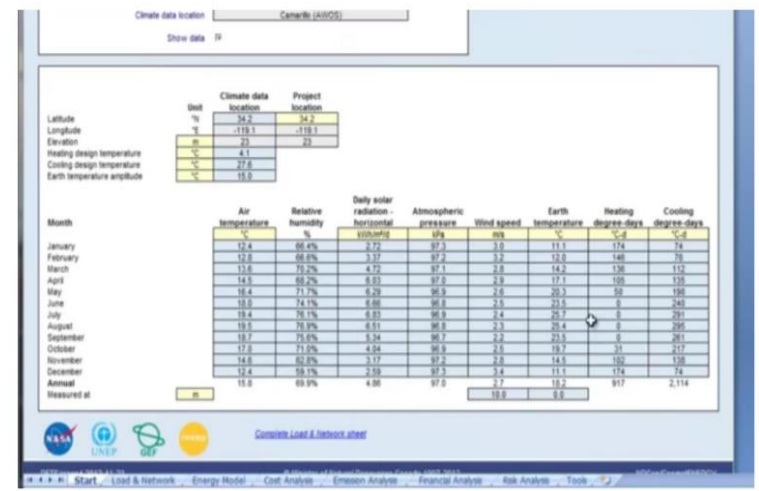

\section{CONCLUSION}

The RETScreen Software objective is to implement renewable energy and energy efficient projects by helping in decision making of project designers and industries. It significantly reduces the cost and helps developers to save time while identifying and assessing potential energy projects at initial planning stage.Solar power is freely and abundantly available in this planet, PV technology is one of the most feasible renewable energy's for electricity generation within the urban environment.

Increasing environmental concerns and the need to achieve emission reduction targets, PV produced clean electricity can displace power generated from fossil fuels; it is this benefit that could lead to its future success.

\section{REFERENCES}

1. A Case Study on Performance Evaluation Of Grid Connected Pv Generation Systems In UAE By Swaroop.R Assistant Professor, UAE

2. https://www.google.co.in/search?q=retscreen\&oq=retscreen\&aqs=chr ome...69i57.5001j0j8 \&sourced=chrome \& ie=UTF-8

3. https://www.google.co.in/search?q=rescreen+pv+pdfs\&oq=rescreen+ pv+pdfs\&aqs=chrom $\quad$ e..69i57.7176j0j8\&sourceid=chrome $\quad \&$ ie $=$ UTF-8

4. http://www.mcit.gov.cy/mcit/mcit.nsf/0/\$file/Retscreen\%20Manual\% 20(CHP).pdf

5. Efficiency Analysis Of The Photovoltaic System For Carbon Reduction By Hossein Jahakhani

6. Feasibility Study Of Small Hydropower Schemes Using Retscreen Software As Decision Support Tool In Giba And Worie Subbasins Of Tekeze River, Ethiopia

7. http://www.esru.strath.ac.uk/EandE/Web_sites/01-02/RE_info/photov oltaics.htm

8. www.retscreen.net

\section{AUTHORS PROFILE}

Mrs. V.Baby Shalini, Assistant professor, Department of EEE, Jawaharlal Nehru Technological University Hyderabad College of Engineering Jagtial, (T.S), INDIA.

Mr. Kandula Praveen, PG Scholar, Dept of EEE, Jawaharlal Nehru Technological University Hyderabad College Of Engineering Jagtial (T.S), INDIA. 